\title{
Calcium Promotes the Accumulation of Polyphosphoinositides in Intact and Permeabilized Bovine Adrenal Chromaffin Cells
}

\author{
David A. Eberhard ${ }^{1,2}$ and Ronald W. Holz ${ }^{1,3}$
}

Received December 10, 1990; accepted February 8, 1991

KEY WORDS: polyphosphoinositides; calcium; chromaffin cells; lipid metabolism.

\section{SUMMARY}

1. Because cellular pools of phosphatidylinositol phosphate and phosphatidylinositol bisphosphate turn over rapidly during phospholipase $\mathrm{C}$ stimulation, the continuing production of inositol phosphates requires continuing synthesis from phosphatidylinositol of the polyphosphoinositides. In the present study in adrenal chromaffin cells, we examined the effects of nicotinic stimulation and depolarization in intact cells and micromolar $\mathrm{Ca}^{2+}$ in permeabilized cells on the levels of labeled polyphosphoinositides. We compared the effects to muscarinic stimulation in intact cells and GTP $\gamma \mathrm{S}$ in permeabilized cells.

2. Nicotinic stimulation, elevated $\mathrm{K}^{+}$, and muscarinic stimulation cause similar production of inositol phosphates (D. A. Eberhard and R. W. Holz, J. Neurochem. 49:1634-1643, 1987). Nicotinic stimulation and elevated $\mathrm{K}^{+}$but not muscarinic stimulation increased the levels of $\left[{ }^{3} \mathrm{H}\right]$ inositol-labeled phosphatidylinositol phosphate by $30-60 \%$ and $\left[{ }^{3} \mathrm{H}\right]$ phosphatidylinositol bisphosphate by $25-30 \%$. The increase required $\mathrm{Ca}^{2+}$ in the medium, was maximal by $1-2 \mathrm{~min}$, and was not preceded by an initial decrease in phosphatidylinositol phosphate and phosphatidylinositol bisphosphate.

3. In digitonin-permeabilized cells, $\mathrm{Ca}^{2+}$ caused as much as a twofold increase in $\left[{ }^{3} \mathrm{H}\right]$ phosphatidylinositol phosphate and $\left[{ }^{3} \mathrm{H}\right]$ phosphatidylinositol bis-

\footnotetext{
${ }^{1}$ Department of Pharmacology, University of Michigan Medical School, Ann Arbor, Michigan 48109.

${ }^{2}$ Current address: Department of Pathology, University of Virginia Health Science Center, Charlottesville, Virginia 22908.

${ }^{3}$ To whom correspondence should be addressed at Department of Pharmacology, M6322 Medical Science I, University of Michigan Medical School, Ann Arbor, Michigan 48109-0626.
} 
phosphate. Similarly, $\mathrm{Ca}^{2+}$ enhanced the production of $\left[{ }^{32} \mathrm{P}\right]$ phosphatidylinositol phosphate and $\left[{ }^{32} \mathrm{P}\right]$ phosphatidylinositol bisphosphate in the presence of $[\gamma$ $\left.{ }^{32} \mathrm{P}\right] \mathrm{ATP}$. In contrast, GTP $\gamma \mathrm{S}$ in permeabilized cells decreased polyphosphoinositides in the presence or absence of $\mathrm{Ca}^{2+}$.

4. The ability of $\mathrm{Ca}^{2+}$ to increase the levels of the polyphosphoinositides decayed with time after permeabilization. The effect of $\mathrm{Ca}^{2+}$ was increased when phosphoesterase and phospholipase $\mathrm{C}$ activities were inhibited by neomycin.

5. These observations suggest that $\mathrm{Ca}^{2+}$ specifically enhances polyphosphoinositide synthesis at the same time that it activates phospholipase C.

\section{INTRODUCTION}

The inositol phospholipids play important roles in regulating cellular functions. The most well-defined function of these lipids is as substrates for receptoractivated phospholipase $\mathrm{C}$, which hydrolyzes phosphatidylinositol bisphosphate $\left(\mathrm{PIP}_{2}\right)$ to form the second messengers inositol trisphosphate $\left(\mathrm{IP}_{3}\right)$ and diacylglycerol (DAG) (Berridge, 1987). Although the production of inositol phosphates by phospholipase $\mathrm{C}$ has been intensively investigated, little is known about the mechanisms controlling the levels of the substrates, phosphatidylinositol

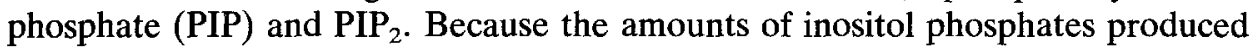
can be many fold greater than changes in the levels of the polyphosphoinositides (Martin et al., 1986) and is closely linked to the turnover of the polyphosphinositides (Agranoff et al., 1983; Downes et al., 1989), regulation of synthesis is crucial for the proper functioning of the phospholipase $\mathrm{C}$ signaling system. Phosphoinositides may also be involved in other cellular processes such as the regulation of protein function. For example, PIP or $\mathrm{PIP}_{2}$ bind to and modulate the in vitro function of the g-actin binding protein profilin (Lassing and Lindberg, 1988; Goldschmidt-Clermont et al., 1990) and the actin severing protein gelsolin (Janmey and Stossel, 1989). The findings that the type I PI kinase tightly associated with and is activated by PDGF receptor/PDGF (Coughlin et al., 1989) and middle $T$ antigen/pp60c-src complexes (Courtneidge and Heber, 1990) suggest that products of this PI kinase (phosphatidylinositol-3-phosphate and lipids derived from phosphatidylinositol-3-phosphate) may participate in a signal transduction mechanism.

Our interest in factors regulating the levels of the polyphosphoinositides stems from studies concerning the role of these lipids in chromaffin cells. Chromaffin cells of the adrenal medulla are specialized for the exocytotic secretion of catecholamine. Secretion from bovine chromaffin cells is triggered by $\mathrm{Ca}^{2+}$ influx following nicotinic stimulation or depolarization of intact cells or by the direct addition of micromolar $\mathrm{Ca}^{2+}$ to permeabilized cells (Knight and Baker, 1982; Dunn and Holz, 1983; Wilson and Kirshner, 1983). $\mathrm{Ca}^{2+}$ also activates phospholipase C in intact and permeabilized cells (Whitaker, 1985; Eberhard and Holz, 1987; Sasakawa et al., 1989; Eberhard et al., 1990). Muscarinic agonists stimulate phospholipase $\mathrm{C}$ in intact bovine chromaffin cells (Eberhard and Holz, 1987; Sasakawa et al., 1989; Plevin and Boarder, 1988), presumably through a 
GTP binding protein. However, muscarinic agonists stimulate little or no secretion, probably because the subsequent increase in cytosolic $\mathrm{Ca}^{2+}$ (Kao and Schneider, 1985) is not adjacent to the plasma membrane (Cheek et al., 1989). We recently found that maintenance of the polyphosphoinositides in permeabilized cells is important for secretion independent of the lipids being substrates for phospholipase C (Eberhard et al., 1990).

In the present study we examined the effects of nicotinic stimulation and depolarization in intact cells and micromolar $\mathrm{Ca}^{2+}$ in permeabilized cells on the levels of labeled polyphosphoinositides. We compared the effects to muscarinic stimulation in intact cells and guanosine $5^{\prime}-[\gamma$-thio $]$ triphosphate (GTP $\left.\gamma S\right)$ in permeabilized cells. We demonstrate a specific $\mathrm{Ca}^{2+}$-dependent increase in the amounts of polyphosphoinositides in both intact and permeabilized cells. These observations suggest that $\mathrm{Ca}^{2+}$ plays an important role in regulating polyphosphoinositide synthesis that is distinct from its ability to activate phospholipase $\mathrm{C}$.

\section{MATERIALS AND METHODS}

Chromaffin cells were isolated by dissociation of bovine adrenal medullae, purified by differential plating (Waymire et al., 1983), and cultured as monolayers in 6.4-mm-diameter collagen-coated wells, 150,000 cells/well as previously described (Holz et al., 1982). The cultures consisted of at least $90 \%$ chromaffin cells and contained virtually no visually detectable fibroblasts or endothelial cells.

Experiments were performed 4-12 days after culture preparation. Cellular inositol-containing lipids were labeled by incubating for 36-60 hr with myo-[2${ }^{3} \mathrm{H}$ ]inositol $(20 \mu \mathrm{Ci} / \mathrm{ml})$ in Eagle's minimal essential medium containing $11 \mu M$ myoinositol (Whittaker M. A. Bioproducts, Walkersville, MD) supplemented with $10 \%$ dialyzed fetal bovine serum (GIBCO Laboratories, Grand Island, NY), glutamine, penicillin, and streptomycin. $\left[{ }^{3} \mathrm{H}\right]$ Inositol incorporation into lipid was maximal after about $48 \mathrm{hr}$ of labeling. Immediately before starting an experiment, the labeling medium was removed and the cells were washed for $15 \mathrm{~min}$ in physiological salt solution (PSS) containing $145 \mathrm{~m} M \mathrm{NaCl}, 5.6 \mathrm{mM} \mathrm{KCl}, 2.2 \mathrm{~m} M$ $\mathrm{CaCl}_{2}, 0.5 \mathrm{~m} M \mathrm{MgCl}_{2}, 5.6 \mathrm{~m} M$ glucose, $0.5 \mathrm{~m} M$ ascorbic acid, and $15 \mathrm{~m} M$ $N$-2-hydroxyethylpiperazine- $N^{\prime}$-2-ethanesulfonic acid (Hepes), pH 7.4. Experiments were initiated by removing the PSS and adding fresh PSS or by permeabilizing the cells with $20 \mu M$ digitonin in a solution (KGEP) containing $139 \mathrm{~m} M$ potassium glutamate, $20 \mathrm{~m} M$ 1,4-piperazinediethanesulfonic acid (Pipes, $\mathrm{pH}$ 6.6), $5 \mathrm{~m} M$ EGTA, and various amounts of Ca to achieve free Ca concentrations calculated (Chang et al., 1988) using the constants of Portzehl et al. (1964). Other components of the KGEP and PSS solutions are detailed in the figure legends. Fifty to one hundred microliters of KGEP was used per well. Experiments with permeabilized cells were usually terminated by quantitatively transferring the incubation solution to tubes containing $1.0 \mathrm{ml}$ ice-cold $\mathrm{H}_{2} \mathrm{O}$.

The samples were stored at $-20^{\circ} \mathrm{C}$ for as long as 2 weeks prior to the analysis of the $\left[{ }^{3} \mathrm{H}\right]$ inositol phosphates. The dilute samples were applied directly to 
anion-exchange columns for the analysis of inositol phosphates as described below. Immediately after removing the incubation solution from the cells, $100 \mu \mathrm{l}$ ice-cold methanol: conc $\mathrm{HCl}(100: 1)$ was added to the culture wells. The wells were scraped and the contents transferred to tubes on ice. The wells were washed with $100 \mu \mathrm{l}$ methanol, which was pooled with the first methanolic solution. Lipids were extracted from the samples on the same day as the experiment. Lipid extracts were stored at $-20^{\circ} \mathrm{C}$ for as long as 1 week prior to separation by thin-layer chromatography (TLC) or anion-exchange chromatography of deacylation products. In experiments with intact cells, trichloroacetic acid (TCA) was added to incubation solution (5\% final TCA concentration; see tables and figures for details). The wells were scraped and TCA-insoluble phospholipids pelleted by centrifugation. Phospholipids in the precipitate were extracted as described below. The supernatent was extracted with $3 \times 5 \mathrm{vol}$ of diethyl ether. Residual ether was evaporated under a $\mathrm{N}_{2}$ stream. The aqueous solutions were brought to $\mathrm{pH}$ 6.5-8.0 with $\mathrm{NaOH}$ and applied to anion-exchange columns for the analysis of inositol phosphates as described below.

Assay of $\left[{ }^{3} \mathrm{H}\right]$ Phosphoinositides. Lipids were extracted by mixing $400 \mu \mathrm{l}$ $\mathrm{CHCl}_{3}$ :methanol $(2: 1)$ with the methanolic samples or TCA precipitates, which were then washed with $250 \mu 10 \mathrm{~m} M$ EDTA in $1 N \mathrm{HCl}$ (vigorous vortexing followed by centrifugation to separate phases). Two hundred microliters of the lower organic phase was transferred to another tube. The upper phase and interface were washed with $200 \mu \mathrm{CHCl}_{3}$, and $200 \mu \mathrm{l}$ of the resulting lower phase was then pooled with the first organic sample. The organic samples $(400 \mu \mathrm{l})$ were washed with $400 \mu \mathrm{l} 10 \mathrm{mM}$ EDTA in $1 N \mathrm{HCl}$ :methanol (1:1). The entire lower phase was transferred to a new tube for subsequent lipid analysis. If lipids were to be separated by TLC, the samples were dried under $\mathrm{N}_{2}$ and redissolved in $\mathrm{CHCl}_{3}$ :methanol $(2: 1)$ before storage at $-20^{\circ} \mathrm{C}$. After each wash in the extraction procedure, the total volumes of the organic phases were measured to determine recoveries.

Anion-exchange chromatography of lipid deacylation products was performed essentially as described by Downes and Michell (1981). The volume of the lipid extract was brought to $500 \mu \mathrm{l}$ with $\mathrm{CHCl}_{3}$. One hundred microliters methanol and $100 \mu \mathrm{l} 1.0 \mathrm{~N} \mathrm{NaOH}$ in methanol: $\mathrm{H}_{2} \mathrm{O}(19: 1)$ were added. After vortexing, the samples were allowed to stand $30 \mathrm{~min}$ at room temperature. The phases were then broken by adding $500 \mu \mathrm{l} \mathrm{CHCl}_{3}, 300 \mu \mathrm{l}$ methanol, and $300 \mu \mathrm{l}$ $\mathrm{H}_{2} \mathrm{O}$, followed by vigorous vortexing and centrifugation. Four hundred fifty microliters of the upper aqueous phase (total volume, $550 \mu \mathrm{l}$ ) was transferred to a new tube, blown briefly under $\mathrm{N}_{2}$ to remove traces of $\mathrm{CHCl}_{3}$, and then diluted to $3.0 \mathrm{ml}$ with $5 \mathrm{~m} M \mathrm{Na}$ tetraborate $/ 60 \mathrm{~m} M \mathrm{Na}$ formate. The samples were applied to 0.3-ml-bed volume Dowex AG1-X3 columns (formate form; Bio-Rad Laboratories, Richmond, CA). The void volume contained $\left[{ }^{3} \mathrm{H}\right]$ glycerophosphoinositol (GPI). [ ${ }^{3} \mathrm{H}$ ]GPI remaining on the columns was eluted with $3 \times 1.0 \mathrm{ml} 5 \mathrm{mM} \mathrm{Na}$ tetraborate $/ 180 \mathrm{mM} \mathrm{NH}$ formate. Each 3.0-ml fraction was mixed with $15 \mathrm{ml}$ Universol ES scintillant (Dupont NEN, Wilmington, DE) for counting. Over $90 \%$ of total $\left[{ }^{3} \mathrm{H}\right] \mathrm{GPI}$ eluted in these fractions. The columns were then washed 
with $4 \times 3 \mathrm{ml}$ of the same buffer; these washes were usually discarded. $\left[{ }^{3} \mathrm{H}\right]$ Glycerophosphoinositol phosphate (GPIP) was eluted with $7 \times 1.0 \mathrm{ml} 0.3 \mathrm{M}$ $\mathrm{NH}_{4}$ formate $/ 0.1 M$ formic acid, recovering $>90 \%$ of the total $\left[{ }^{3} \mathrm{H}\right] \mathrm{GPIP} ; 3.5-\mathrm{ml}$ fractions were counted with $17 \mathrm{ml}$ Universol ES. The columns were further washed with $4 \times 3 \mathrm{ml}$ of the same buffer; the washes were usually discarded. $\left[{ }^{3} \mathrm{H}\right]$ Glycerophosphoinositol bisphosphate $\left(\mathrm{GPIP}_{2}\right)$ was eluted quantitatively with $4 \times 1.0 \mathrm{ml} 1.0 \mathrm{M} \mathrm{NH}_{4}$ formate $/ 1.0 \mathrm{M}$ formic acid and counted as a single fraction with $15 \mathrm{ml}$ Universol $\mathrm{ES}$. The deacylation procedure quantitatively converted organic-soluble ${ }^{3} \mathrm{H}$ to aqueous ${ }^{3} \mathrm{H}$. Aqueous contamination of the organic extracts was assessed by processing samples as described with the substitution of methanol for methanolic $\mathrm{NaOH}$ in the deacylation step. Contamination accounted for about $0.6 \%$ of $\left[{ }^{3} \mathrm{H}\right] \mathrm{GPI}$ and about $1.3 \%$ of both $\left[{ }^{3} \mathrm{H}\right] \mathrm{GPIP}$ and $\left[{ }^{3} \mathrm{H}\right] \mathrm{GPIP}{ }_{2}$.

Lipid Phosphorylation. Cells were permeabilized with KGEP containing $20 \mu M$ digitonin, $\left[\gamma-{ }^{32} \mathrm{P}\right] \mathrm{MgATP}(50-100 \mathrm{Ci} / \mathrm{mol})$, and other additions as noted. Incubations were terminated and lipids extracted as described above. Organic extracts were spotted on silica gel $\mathrm{HL}$ plates and developed in $\mathrm{CHCl}_{3}$ (44) : methanol (44) $: \mathrm{H}_{2} \mathrm{O}$ (7):30\% $\mathrm{NH}_{4} \mathrm{OH}$ (5). Bands were visualized by autoradiography, scraped, and counted in 4-ml Universol ES scintillant. The only lipids labeled under these conditions were the direct products of lipid kinases; $\mathrm{PIP}_{2}$, PIP, and PA. PI was not labeled because small molecules required for PI synthesis from PA (inositol and CTP) were rapidly lost from the permeabilized cells (authors' unpublished observations).

Assays of $\left[{ }^{3} \mathrm{H}\right]$ Inositol Phosphates. $\left[{ }^{3} \mathrm{H}\right]$ Inositol phosphates were separated by anion-exchange chromatography according to Berridge et al. (1983). The samples were applied to Dowex AG1-X8 columns (formate form, 0.3-ml bed volume). Free inositol and GPI were eluted with $8 \times 1.0-\mathrm{ml}$ washes of $5 \mathrm{mM} \mathrm{Na}$ tetraborate $/ 60 \mathrm{~m} M \mathrm{Na}$ formate. These washes were usually discarded. $\left[{ }^{3} \mathrm{H}\right] \mathrm{IP}_{1}$ was eluted with $3 \times 1.0 \mathrm{ml} 0.2 \mathrm{M} \mathrm{NH}_{4}$ formate $/ 0.1 M$ formic acid; the columns were then washed with $3 \times 1.0 \mathrm{ml}$ of the same buffer. $\left[{ }^{3} \mathrm{H}\right] \mathrm{IP}_{2}$ was eluted with $7 \times 1.0 \mathrm{ml} 0.4 M \mathrm{NH}_{4}$ formate $/ 0.1 M$ formic acid, followed by $3 \times 3.0-\mathrm{ml}$ washes with the same buffer. $\left[{ }^{3} \mathrm{H}\right] \mathrm{IP}_{3}$ was eluted with $4 \times 1.0 \mathrm{ml} 1.0 \mathrm{M} \mathrm{NH}_{4}$ formate $/ 0.1 \mathrm{M}$ formic acid. Radioactivity in the eluates was determined by scintillation counting as described above. The $\mathrm{IP}_{3}$ fraction also contains $\mathrm{IP}_{4}$ (Batty et al., 1985).

Data Analysis. Unless otherwise indicated, the figures and the tables show data from individual experiments representative of similar experiments performed in two or more cell culture preparations. Data shown are average counts per minute (cpm) per well \pm SE. There were four wells per group. Error bars smaller than the data point symbols were omitted. Differences between the means of groups were tested for significance with Student's $t$ test. The standard error of the mean associated with the difference between the means of two groups was calculated by $\left(\mathrm{SE}_{1}^{2}+\mathrm{SE}_{2}^{2}\right)^{1 / 2}$.

Materials. All reagents were obtained from standard commercial sources. Myo-[2- $\left.{ }^{3} \mathrm{H}\right]$ inositol $(1 \mathrm{mCi} / \mathrm{ml}, 10-30 \mathrm{Ci} / \mathrm{mmol})$ was from American Radiolabeled Chemicals (St. Louis, MO). Polar contaminants were removed before use by mixing a few milligrams of Dowex AG1-X8 with aqueous $\left[{ }^{3} \mathbf{H}\right]$ inositol. $[\gamma-$ 
${ }^{32}$ P]ATP was from Amersham Corp. (Arlington Heights, IL). GTP $\gamma$ S (Li salt) was from Boehringer Mannheim Biochemicals (Indianopolis, IN).

\section{RESULTS}

Effects of Stimulation of Intact Chromaffin Cells on the Levels of the Polyphosphoinositides. Stimulation of $\left[{ }^{3} \mathrm{H}\right]$ inositol-prelabeled chromaffin cells with the nicotinic agonist DMPP increased the levels of $\left[{ }^{3} \mathrm{H}\right] \mathrm{PIP}$ and $\left[{ }^{3} \mathrm{H}\right] \mathrm{PIP}_{2}$ within $1 \mathrm{~min}$ of stimulation (Fig. 1). The most prominent increase was in [ $\left.{ }^{3} \mathrm{H}\right] \mathrm{PIP}$, which was maximal (approximately $50 \%$ increase) by 2 min after the addition of DMPP. The DMPP-stimulated increments in $\left[{ }^{3} \mathrm{H}\right] \mathrm{PIP}$ and $\left[{ }^{3} \mathrm{H}\right] \mathrm{PIP}_{2}$ consisted entirely of the PI-4-P and P-4,5-P $\mathrm{P}_{2}$ isomers, respectively (D. A. Eberhard, R. W. Holz, and L. L. Cantley, unpublished observations). DMPP also increased $\left[{ }^{3} \mathrm{H}\right] \mathrm{IP}_{2}$ and $\left[{ }^{3} \mathrm{H}\right] \mathrm{IP}_{3}$ as has been described previously (Eberhard and Holz, 1987).

The increase in $\left[{ }^{3} \mathrm{H}\right]$ polyphosphoinositide levels after cell stimulation probably resulted from $\mathrm{Ca}^{2+}$ influx. Table I shows that depolarization of the cells with elevated $\mathrm{K}^{+}$caused an increase in $\left[{ }^{3} \mathrm{H}\right] \mathrm{PIP}$ and $\left[{ }^{3} \mathrm{H}\right] \mathrm{PIP}_{2}$ similar to that seen with

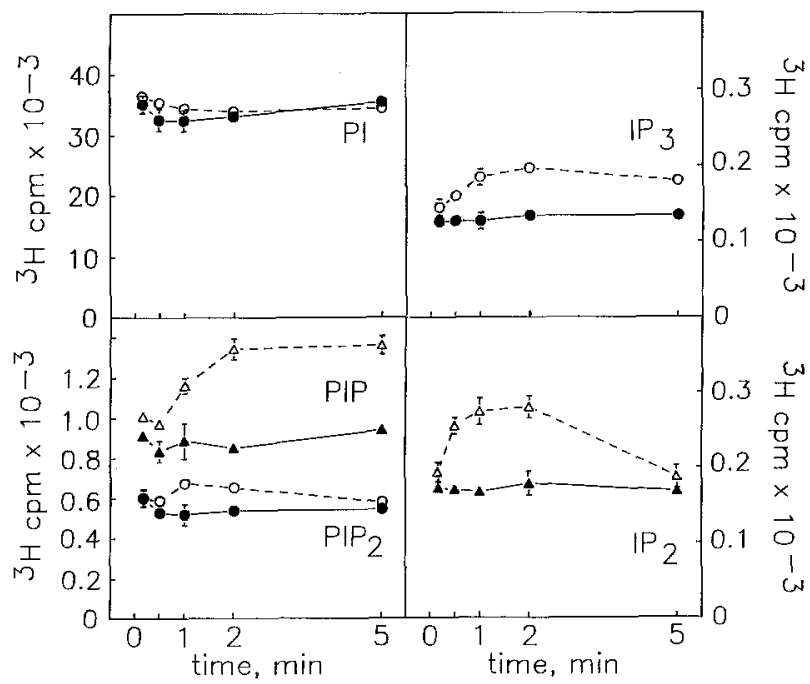

Fig. 1. Time course of DMPP effects on $\left[{ }^{3} \mathrm{H}\right]$ inositol phospholipids and $\left[{ }^{3} \mathrm{H}\right]$ inositol phosphates. Chromaffin cells prelabeled with $\left[{ }^{3} \mathrm{H}\right]$ inositol were incubated with $50 \mu \mathrm{l}$ PSS containing $2.2 \mathrm{mM} \mathrm{CaCl}$ and $2 \mathrm{mg} / \mathrm{ml} \mathrm{BSA} \mathrm{(CaPSS-BSA)} \mathrm{for} 30 \mathrm{~min}$. CaPSS-BSA $(100 \mu$ l) with $15 \mu M$ DMPP (open symbols, dashed lines) or without DMPP (filled symbols, solid lines) was then added to the wells (final [DMPP] $=10 \mu M$ when present. After continuing the incubations for $10 \mathrm{sec}-5 \mathrm{~min}$ as indicated, $150 \mu \mathrm{l}$ ice-cold $10 \%$ TCA was added to the wells (final $[\mathrm{TCA}]=5 \%$ ) and the cells were processed for determination of $\left[{ }^{3} \mathrm{H}\right]$ inositol lipids and $\left[{ }^{3} \mathrm{H}\right]$ inositol phosphates as described under Materials and Methods. The left ordinates correspond to the left panels; the right ordinates correspond to the right panels. 


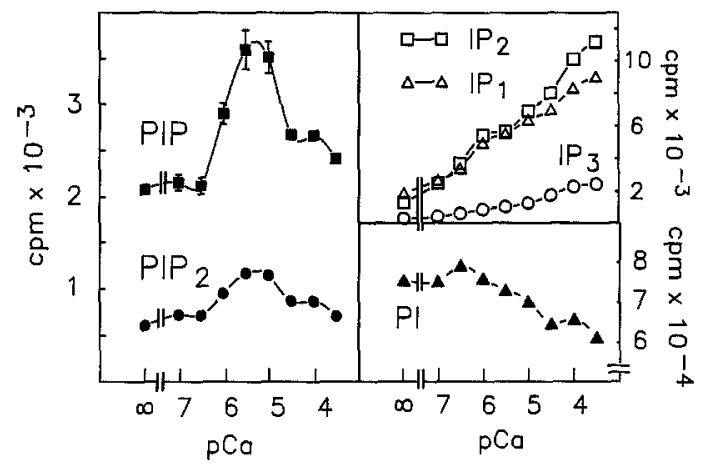

Fig. 2. Concentration-response relationships for $\mathrm{Ca}^{2+}$ on phosphoinositide levels and release of inositol phosphates. $\left[{ }^{3} \mathrm{H}\right]$ Inositol-prelabeled cells were incubated $15 \mathrm{~min}$ with $\mathrm{KGEP}$ containing $20 \mu \mathrm{M}$ digitonin, $2 \mathrm{~m} M \mathrm{MgATP}$, and various concentrations of free $\mathrm{Ca}^{2+}$ as indicated. The incubation medium was then removed and methanol: $\mathrm{HCl}(50: 1)$ was added to the cells. $\left.{ }^{3} \mathrm{H}\right]$ Inositol phosphates released into the medium and cellular $\left[{ }^{3} \mathrm{H}\right]$ lipids were assayed (see Materials and Methods). $p \mathrm{Ca}$ is $-\log \left[\mathrm{Ca}^{2+}\right]$. The left ordinate corresponds to the left panel; the right ordinates correspond to the right panels.

$\mathrm{PIP}_{2}$ in permeabilized cells (Table II). [ $\left.{ }^{32} \mathrm{P}\right] \mathrm{PA}$ was also increased, presumably reflecting the phosphorylation of diacylglycerol produced by phospholipase $\mathrm{C}$ activity. GTP- $\gamma$-S $(100 \mu M)$, which stimulates approximately the same production of inositol phosphates production as $10 \mu M \mathrm{Ca}^{2+}$ (Eberhard et al., 1990), caused an increase in phosphorylated diacylglycerol similar to that produced by $10 \mu M$ $\mathrm{Ca}^{2+}$ but decreased the amounts of $\left[{ }^{32} \mathrm{P}\right] \mathrm{PIP}$ and $\left[{ }^{32} \mathrm{P}\right] \mathrm{PIP}_{2}$. The addition of GTP- $\gamma$-S together with $\mathrm{Ca}^{2+}$ prevented the increase in PIP and $\mathrm{PIP}_{2}$ by $\mathrm{Ca}^{2+}$ and further increased $\left[{ }^{32} \mathrm{P}\right] \mathrm{PA}$ formation, suggesting that polyphosphoinositides which would have accumulated in the presence of $\mathrm{Ca}^{2+}$ alone were hydrolyzed by GTP- $\gamma$-S-activated phospholipase C. The data demonstrate that the ability of

Table II. Effect of $\mathrm{Ca}^{2+}$ and GTP $\gamma \mathrm{S}$ on Lipid Phosphorylation ${ }^{a}$

\begin{tabular}{|c|c|c|c|}
\hline \multirow{6}{*}{$\begin{array}{l}\text { No additions } \\
\mathrm{Ca}^{2+} \\
\mathrm{GTP}_{\gamma} \mathrm{S} \\
\mathrm{Ca}^{2+}+\mathrm{GTP} \gamma \mathrm{S}\end{array}$} & \multicolumn{3}{|c|}{ cpm/well } \\
\hline & PIP $_{2}$ & PIP & PA \\
\hline & $195 \pm 12 \quad(100)$ & $255 \pm 10 \quad(100)$ & $320 \pm 7 \quad(100)$ \\
\hline & $400 \pm 17^{*}(205)$ & $390 \pm 16^{*}$ & $826 \pm 25^{*}(258)$ \\
\hline & $141 \pm 15$ & $123 \pm 6^{*}$ & $873 \pm 43^{*}(254)$ \\
\hline & $122 \pm 8^{*}$ & $115 \pm 10^{*}$ & $1412 \pm 31^{*}(441)$ \\
\hline
\end{tabular}

${ }^{a}$ Cells were permeabilized $5 \mathrm{~min}$ in the presence of $5 \mathrm{mM} \mathrm{Mg}\left[\gamma-{ }^{32} \mathrm{P}\right]$ ATP with either no additions, $10 \mu M \mathrm{Ca}^{2+}, 100 \mu M \mathrm{GTP} \gamma \mathrm{S}$, or $\mathrm{Ca}^{2+}+\mathrm{GTP} \gamma \mathrm{S}$. Incubations were terminated and $\left[{ }^{32} \mathrm{P}\right]$ lipids quantitated by TLC as described under Materials and Methods. The $\mathrm{cpm} /$ well of the groups in each column expressed as the percentage of no additions is shown in parentheses. There were four wells per group.

$* P<0.01$ compared to no additions. 
$\mathrm{Ca}^{2+}$ to promote increases in labeled polyphosphoinositides is specific and does not reflect a generalized secondary response to phospholipase $\mathrm{C}$ activation.

Effect of Neomycin on $\mathrm{Ca}^{2+}$-Induced Increases in the Polyphosphoinositides. $\mathrm{Ca}^{2+}$ could increase levels of polyphosphoinositides by activating PI or PIP kinase or by inhibiting phosphomonoesterases. The polycation neomycin binds through ionic interactions with the highly charged anionic phosphoinositides, protecting the headgroups from phosphatase and phospholipase C activities (Schacht, 1976; Schacht, 1978; Downes and Michell, 1981). We recently demonstrated in digitonin permeabilized cells that neomycin protects the polyphosphoinositides from breakdown in the absence of MgATP (Eberhard et al., 1990). We also found that neomycin enhances the levels of the polyphosphoinositides in the presence of MgATP (C. L. Cooper and R. W. Holz, manuscript in preparation). The latter effect probably results from inhibited polyphosphoinositide phosphatase activity and continuing polyphosphoinositide synthesis. If $\mathrm{Ca}^{2+}$ stimulates PI or PIP kinase, the $\mathrm{Ca}^{2+}$-induced increase in polyphosphoinsoitides should be enhanced by phosphatase and phospholipase $C$ inhibition caused by neomycin. Conversely, if the $\mathrm{Ca}^{2+}$-induced increases in PIP and $\mathrm{PIP}_{2}$ levels result from inhibition of PIP or PIP $_{2}$ phosphatases (or activation of phospholipase $\mathrm{C}$ ), the effect of $\mathrm{Ca}^{2+}$ should be reduced when these enzymes are simultaneously inhibited by neomycin. Table III shows the result of such an experiment. Permeabilizing $\left[{ }^{3} \mathrm{H}\right]$ inositol-prelabeled cells in the presence of neomycin $(250 \mu M)$ increased the basal levels of $\left[{ }^{3} \mathrm{H}\right] \mathrm{PIP}$ and $\left[{ }^{3} \mathrm{H}\right] \mathrm{PIP}{ }_{2}$. Neomycin did not inhibit the effects of $\mathrm{Ca}^{2+}$ on the polyphosphoinositides. Instead, neomycin increased the $\mathrm{Ca}^{2+}$-induced increments in $\left[{ }^{3} \mathrm{H}\right] \mathrm{PIP}{ }_{2}$ and $\left[{ }^{3} \mathrm{H}\right] \mathrm{PIP} 2.12-$

Table III. Effect of $\mathrm{Ca}^{2+}$ on $\left[{ }^{3} \mathrm{H}\right] \mathrm{PIP}$ and $\left[{ }^{3} \mathrm{H}\right] \mathrm{PIP}_{2}$ Levels in the Absence and Presence of Neomycin ${ }^{a}$

\begin{tabular}{lll}
\hline & \multicolumn{2}{c}{$\%$ of total ${ }^{3} \mathrm{H}$} \\
\cline { 2 - 3 } Addition & \multicolumn{1}{c}{$\mathrm{PIP}$} & $\mathrm{PIP}_{2}$ \\
\hline - neomycin & & \\
$-\mathrm{Ca}^{2+}$ & $1.86 \pm 0.06$ & $0.600 \pm 0.017$ \\
$+\mathrm{Ca}^{2+}$ & $3.40 \pm 0.11^{*}$ & $1.116 \pm 0.045^{*}$ \\
$\mathrm{Ca}^{2+}$ dependent & $1.54 \pm \mathbf{0 . 1 2}$ & $0.516 \pm 0.048$ \\
+ neomycin & & \\
$-\mathrm{Ca}^{2+}$ & $3.31 \pm 0.07$ & $1.93 \pm 0.05$ \\
$+\mathrm{Ca}^{2+}$ & $5.43 \pm 0.05^{*}$ & $3.03 \pm 0.07^{*}$ \\
$\mathrm{Ca}^{2+}$ dependent & $2.12 \pm 0.09$ & $1.10 \pm 0.09$ \\
\hline
\end{tabular}

${ }^{a}\left[{ }^{3} \mathrm{H}\right]$ Inositol-prelabeled cells were permeabilized for $15 \mathrm{~min}$ with KGEP containing $20 \mu M$ digitonin, $3 \mathrm{mM} \mathrm{MgATP}$, with or without neomycin $(250 \mu M)$ as indicated and with or without added $\mathrm{Ca}^{2+}(10 \mu M)$ as indicated. The incubations were terminated by removing the permeabilization medium and adding 5\% TCA to the wells. $\left[{ }^{3} \mathrm{H}\right]$ Inositol phospholipids were quantitated by anion-exchange chromatography of deacylation products as described under Materials and Methods. Data are expressed as the percentage of total radioactivity present in lipids and inositol phosphates $\pm \mathrm{SE}$. The $\mathrm{Ca}^{2+}$-dependent accumulations were calculated as the difference between the " $+\mathrm{Ca}^{2+"}$ " and the "- $\mathrm{Ca}^{2+"}$ groups. There were four wells per group.

$* P<0.001 \mathrm{vs}-\mathrm{Ca}^{2+}$. 
and 1.38-fold, respectively. In another experiment the increases were 2.13- and 1.01-fold, respectively. Under these conditions, phospholipase $\mathrm{C}$ activity was inhibited approximately 50\% (data not shown). Thus, neomycin, which inhibits the degradation of the polyphosphoinositides, augmented the $\mathrm{Ca}^{2+}$-dependent increase in the polyphosphoinositides. The predominant increase in $\left[{ }^{3} \mathrm{H}\right] \mathrm{PIP}_{2}$ rather than $\left[{ }^{3} \mathrm{H}\right] \mathrm{PIP}$ may reflect $\mathrm{Ca}^{2+}$-induced stimulation of PIP as well as $\mathrm{PIP}_{2}$ synthesis since PIP is a precursor of $\mathrm{PIP}_{2}$. Because neomycin inhibits $\mathrm{Ca}^{2+}$ dependent secretion when present together with $\mathrm{Ca}^{2+}$ in permeabilized cells (Bittner et al., 1986), the experiment rules out the possibility that the effects of $\mathrm{Ca}^{2+}$ on the polyphosphoinositides are caused by exocytosis.

The Effects of $\mathrm{Ca}^{2+}$ on PI Metabolism May Be Mediated by Soluble Factors. The ability of $\mathrm{Ca}^{2+}$ to increase the polyphosphoinositides became progressively smaller as the time between the initial permeabilization with digitonin and the subsequent $\mathrm{Ca}^{2+}$ challenge increased (Fig. 3). The maximal increase in polyphosphoinositides occurred when $\mathrm{Ca}^{2+}$ was added together with digitonin. The ability of $\mathrm{Ca}^{2+}$ to stimulate phosphoinositide $\left[{ }^{32} \mathrm{P}\right] \mathrm{phosphorylation}$ was also lost with increasing permeabilization time (data not shown). It is unlikely that phosphoinositide kinase or phosphatase activities are lost after permeabilization, since the basal levels of PIP ${ }_{2}$ and PIP were maintained (in the presence of millimolar MgATP) for at least $18 \mathrm{~min}$ in permeabilized cells (Eberhard et al., 1990). Indeed, permeabilization with digitonin for up to $10 \mathrm{~min}$ did not reduce cellular PI kinase activity, assayed with exogenous PI in Triton X-100 lysates (data not shown). The loss of responses to $\mathrm{Ca}^{2+}$ with increasing permeabilization time suggests that the responses may involve a soluble factor which is lost from the cells.

PI kinase activity was not increased by $\mathrm{Ca}^{2+}(10 \mu M)$ in chromaffin cell homogenates or in homogenates prepared from $\mathrm{Ca}^{2+}$-stimulated cells (data not shown). It is unlikely that the $\mathrm{Ca}^{2+}$ effects in cells are mediated by calmodulin or protein kinase $\mathrm{C}$. The calmodulin binding peptide $\mathrm{Ca}^{2+} /$ calmodulin kinase II(291-317) and the protein kinase C inhibitory peptide PKC(19-31) (House and Kemp, 1987) at concentrations which selectively inhibit $\mathrm{Ca}^{2+}-$ or TPA-induced protein phosphorylation in permeabilized chromaffin cells [3 and $10 \mu M$,

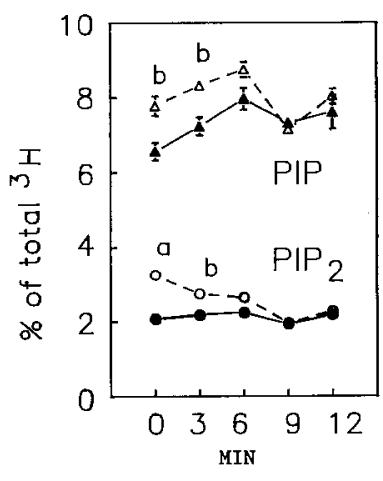

PERMEABILIZATION TIME
Fig. 3. Rundown of $\mathrm{Ca}^{2+}$ effects in permeabilized cells. $\left[{ }^{3} \mathrm{H}\right]$ Inositol-prelabeled cells were permeabilized in KGEP containing $20 \mu M$ digitonin and $2 \mathrm{mM} \mathrm{MgATP}$ for the indicated times (permeabilization time). The permeabilizing medium was then removed, and fresh medium, containing digitonin, MgATP, and either $0 \mathrm{Ca}$ (filled symbols) or $10 \mu M$ free $\mathrm{Ca}$ (open symbols), was added. After $15 \mathrm{~min}$ the medium was removed and assayed for $\left[{ }^{3} \mathrm{H}\right] \mathrm{IP}{ }_{1}$ and $\left[{ }^{3} \mathrm{H}\right]$ inositol polyphosphates (IPP) as described under Materials and Methods. $\left[{ }^{3} \mathrm{H}\right]$ Inositol phospholipids remaining in the cells were assayed by anion-exchange chromatography of the deacylation products. The data were normalized as the percentage of the sum of $\left[{ }^{3} \mathrm{H}\right]$ inositol phosphates $+\left[{ }^{3} \mathrm{H}\right]$ inositol phospholipids (\% of total ${ }^{3} \mathrm{H}$ ). Significant differences between Ca-treated and untreated groups in $\mathrm{PIP}_{2}$ and PIP are (a) $P<0.001$ and (b) $P<0.01$. 
respectively (TerBush and Holz, 1990)] did not alter $\left[{ }^{3} \mathrm{H}\right] \mathrm{phosphoinositide} \mathrm{levels}$ or $\left[{ }^{3} \mathrm{H}\right]$ inositol phosphates released in the presence or absence of $\mathrm{Ca}^{2+}$ in permeabilized cells.

\section{DISCUSSION}

Hormone or neurotransmitter receptors acting through a GTP binding protein or $\mathrm{Ca}^{2+}$ entry into cells can stimulate phospholipase $\mathrm{C}$ activity and produce inositol phosphates (Berridge, 1987; Eberhard and Holz, 1987; Eberhard and Holz, 1988). Because the amount of inositol phosphates produced can be manyfold greater than the changes in the polyphosphoinositide levels, the continuing production of inositol phosphates requires continuing synthesis of the polyphosphoinositides from PI via PI and PIP kinases. An initial loss of polyphosphoinositides upon phospholipase $\mathrm{C}$ activation followed by a compensatory increase in synthesis has been observed in thrombin-stimulated platelets (Agranoff et al., 1983), vasopressin-treated hepatocytes (Creba et al., 1983), pituitary cells stimulated with TRH (Rebecchi and Gershengorn, 1983), and fibroblast homogenates stimulated with GTP $\gamma$ S (Chahwala et al., 1987).

In the present study, the amounts of the inositol phosphates produced in permeabilized cells were manyfold greater than the total polyphosphoinositides (Fig. 2). One possible mechanism for regulating the synthesis of the polyphosphoinositides is through product inhibition which is relieved by activation of phospholipase C (Van Rooijen et al., 1985). In this case, activation of phospholipase $\mathrm{C}$ by different mechanisms should have similar effects on the levels of the polyphosphoinositides. We have investigated in intact and permeabilized adrenal chromaffin cells the effects of different phospholipase $\mathrm{C}$ activators on polyphosphoinositide levels. We found that nicotinic agonist in the presence of $\mathrm{Ca}^{2+}$ in intact cells or micromolar $\mathrm{Ca}^{2+}$ in permeabilized cells, in addition to strongly activating phospholipase $\mathrm{C}$, increased the polyphosphoinositides. In contrast, muscarinic receptor activation in intact cells or GTP $\gamma \mathrm{S}$ in permeabilized cells, which also strongly activates phospholipase $\mathrm{C}$, had no effect (intact cells) or decreased (permeabilized cells) the levels of the polyphosphoinositides. Neomycin, which inhibits polyphosphoinositide hydrolysis by phospholipase $\mathrm{C}$, enhanced the effects of $\mathrm{Ca}^{2+}$. These experiments indicate for the first time that micromolar $\mathrm{Ca}^{2+}$ regulates the cellular levels of the polyphosphoinositides through a specific mechanism that is not simply coupled to phospholipase $\mathrm{C}$ activation.

Micromolar $\mathrm{Ca}^{2+}$ could specifically increase the polyphosphoinositides by increasing synthesis and/or decreasing metabolism. Neomycin, which inhibits polyphosphoinositide phosphatases and phospholipase C (Schacht, 1976; Eberhard et al., 1990), augmented the increases caused by $\mathrm{Ca}^{2+}$, which suggests that $\mathrm{Ca}^{2+}$ increased polyphosphoinositide synthesis. Experiments with sea urchin cortices (Oberdorf et al., 1989) and rat liver membranes (Whipps et al., 1987) are consistent with $\mathrm{Ca}^{2+}$ being able to activate polyphosphoinositide synthesis. Pulse-chase experiments with $\left[\gamma_{-}{ }^{32} \mathrm{P}\right] \mathrm{ATP}$ in permeabilized cells were inconclusive in determining whether PIP or PIP $_{2}$ phosphatase activities were decreased by 
$\mathrm{Ca}^{2+}$ (data not shown). Because the ability of $\mathrm{Ca}^{2+}$ to increase the polyphosphoinositides was lost with time after permeabilization (Fig. 3), it is possible that the $\mathrm{Ca}^{2+}$-dependent regulation of polyphosphoinositide levels is mediated through a soluble factor that is lost from permeabilized cells.

It has been reported that micromolar $\mathrm{Ca}^{2+}$ inhibits the PI kinase activity of purified chromaffin granule membranes (Husebye and Flatmark, 1988). The present study indicates that in intact and permeabilized cells, micromolar $\mathrm{Ca}^{2+}$ increases rather than decreases polyphosphoinositide synthesis. We were unable to detect an effect of micromolar $\mathrm{Ca}^{2+}$ on PI kinase activity in chromaffin cell homogenates (data not shown). It is possible that PI kinase in the plasma membrane is the predominant PI kinase activity in chromaffin cells and differs from PI kinase in chromaffin granule membranes.

We have previously suggested that an increase in intracellular $\mathrm{Ca}^{2+}$ acting at the level of phospholipase $\mathrm{C}$ promotes hormone-induced generation of $\mathrm{IP}_{3}$ and diacylglycerol (Eberhard and Holz, 1988). The present study indicates that $\mathrm{Ca}^{2+}$ could also enhance the production of these second messengers by increasing the synthesis of the phospholipase C substrates.

In addition to the importance of polyphosphoinositides in the generation of $\mathrm{IP}_{3}$ and $\mathrm{DAG}$ via phospholipase $\mathrm{C}$, the polyphosphoinositides may play a more direct role in secretion. We have observed that secretion in permeabilized cells is closely correlated with the levels of the polyphosphoinositides but not with phospholipase $C$ activity (Eberhard et al., 1990). The experiments suggested that the polyphosphoinositides play a role in secretion in addition to their being substrates for the generation of $\mathrm{IP}_{3}$ and DAG. Thus, the effects of $\mathrm{Ca}^{2+}$ on the levels of the polyphosphoinositides may not only affect the production of $\mathrm{IP}_{3}$ and DAG but also secretion through a separate, as yet unknown mechanism.

\section{ACKNOWLEDGMENTS}

We thank Dr. Howard Schulman (Stanford University, Stanford, CA) for $\mathrm{Ca}^{2+} /$ calmodulin kinase $\mathrm{II}(291-317)$. This work was supported by U.S. Public Health Service Grants R01AM27959 and P01 HL18575. R.H.W. was an Established Investigator of the American Heart Association when these studies were performed. D.A.E. was supported by a Lutheran Brotherhood Medical Scientist Scholarship.

\section{REFERENCES}

Agranoff, B. W., Murthy, P., and Seguin, E. B. (1983). Thrombin-induced phosphodiesteratic cleavage of phosphatidylinsoitol bisphosphate in human platelets. J. Biol. Chem. 258:2076-2078.

Batty, I. R., Nahorski, S. R., and Irvine, R. F. (1985). Rapid formation of inositol 1,3,4,5tetrakisphosphate following muscarinic receptor stimulation of rat cerebral cortical slices. Biochem. J. 232:211-215. 
Berridge, M. J. (1987). Inositol trisphosphate and diacylglycerol: Two interacting second messengers. Annu. Rev. Biochem. 56:159-193.

Berridge, M. J., Dawson, R. M. C., Downes, C. P., Heslop, J. P., and Irvine, R. F. (1983). Changes in the levels of inositol phosphates after agonist-dependent hydrolysis of membrane phosphoinositides. Biochem. J. 212:473-482.

Bittner, M. A., Holz, R. W., and Neubig, R. R. (1986). Guanine nucleotide effects on catecholamine secretion from digitonin-permeabilized adrenal chromaffin cells. J. Biol. Chem. 261:10182-10188.

Chahwala, S. B., Fieischman, L. F., and Cantley, L. (1987). Kinetic analysis of guanosine 5'-0-(3-thiotriphosphate) effects on phosphatidylinositol turnover in NRK cell homogenates. Biochemistry 26:612-622.

Chang, D., Hsieh, P. S., and Dawson, D. C. (1988). A program in BASIC for calculating the composition of solutions with specified free concentrations of calcium, magnesium and other divalent cations. Comput. Biol. Med. 18:351-366.

Cheek, T. R., O'Sullivan, A. J., Moreton, R. B., Berridge, M. J., and Burgoyne, R. D. (1989). Spatial localization of the stimulus-induced rise in ctyosolic $\mathrm{Ca}^{2+}$ in bovine adrenal chromaffin cells: Distinct nicotinic and muscarinic patterns. FEBS Lett. 247:429-434.

Coughlin, S. R., Escobedo, J. A., and Williams, L. T. (1989). Role of phosphatidylinositol kinase in PDGF receptor signal transduction. Science 243:1191-1194.

Courtneidge, S. A., and Heber, A. (1990). An $81 \mathrm{kd}$ protein complexed with middel $\mathrm{T}$ antigen and pp60c-src: A possible phosphatidylinositol kinase. Cell 50:1031-1037.

Creba, J. A., Downes, C. P., Hawkins, P. T., Brewster, G., Michell, R. H., and Kirk, C. J. (1983). Rapid breakdown of phosphatidylinositol 4-phosphate and phosphatidylinositol 4,5-bisphosphate in rat hepatocytes stimulates by vasopressin and other $\mathrm{Ca}^{2+}$-mobilizing hormones. Biochem. J. 212:733-747.

Downes, C. P., and Michell, R. H. (1981). The polyphosphoinositide phosphodiesterase of erythrocyte membranes. Biochem. J. 198:133-140.

Downes, C. P., Hawkins, P. T., and Stephens, L. (1989). Identification of the stimulated reaction in intact cells, its substrate supply and the metabolism of inositol phosphates. In Inositol Lipids in Cell Signalling (R. H. Drummond, A. H. Drummond and C. P. Downes, Eds.), Academic Press, New York, 1989, pp. 3-38.

Dunn, L. A., and Holz, R. W. (1983). Catecholamine secretion from digitonin-treated adrenal medullary chromaffin cells. J. Biol. Chem. 258:4989-4993.

Eberhard, D. A., and Holz, R. W. (1987). Cholinergic stimulation of inositol phosphate formation in bovine adrenal chromaffin cells: Distinct nicotinic and muscarinic mechanisms. J. Neurochem. 49:1634-1643.

Eberhard, D. A., and Holz, R. W. (1988). Intracellular $\mathrm{Ca}^{2+}$ activates phospholipase C. Trends Neurosci. 11:517-520.

Eberhard, D. A., Cooper, C. L., Low, M. G., and Holz, R. W. (1990). Evidence that the inositol phospholipids are necessary for exocytosis: Loss of inositol phospholipids and inhibition of secretion in permeabilized cells caused by a bacterial phospholipase $C$ and removal of ATP. Biochem. J. 268:15-25.

Goldschmidt-Clermont, P. J., Machesky, L. M., Baldassare, J. J., and Pollard, T. D. (1990). The actin-binding protein porfilin binds to PIP2 and inhibits its hydrolysis by phospholipase C. Science 247:1575-1578.

Holz, R. W., Senter, R. A., and Frye, R. A. (1982). Relationship between $\mathrm{Ca}^{2+}$ uptake and catecholamine secretion in primary dissociated cultures of adrenal medulla. J. Neurochem. 39:635-646.

House, C., and Kemp, B. E. (1987). Protein kinase C contains a pseudosubstrate prototype in its regulatory domain. Science 238:1726-1728.

Husebye, E. S., and Flatmark, T. (1988). Phosphatidylinositol kinase of bovine adrenal chromaffin granules: Kinetic properties and inhibition by low concentrations of $\mathrm{Ca}^{2+}$. Biochim. Biophys. Acta 968:261-265.

Janmey, P. A., and Stossel, T. P. (1989). Gelsolin-polyphosphoinositide interaction: Full expression of gelsolin-inhibiting function by polyphosphoinositides in vesicular form and inactivation by dilution, aggregation, or masking of the inositol head group. J. Biol. Chem. 264:4825-4831.

Kao, L.-S., and Schneider, A. S. (1985). Muscarinic receptors on bovine chromaffin cells mediate a rise in cytoplasmic calcium that is independent of extracellular calcium. J. Biol. Chem. 260:2019-2022.

Knight, D. E., and Baker, P. F. (1982). Calcium-dependence of catecholamine release from bovine adrenal medullary cells after exposure to intense electric fields. J. Membrane Biol. 68:107-140. 
Lassing, I., and Lindberg, U. (1988). Specificity of the interaction between phosphatidylinositol 4,5-bisphosphate and the profilin: actin complex. J. Cell Biochem. 37:255-267.

Martin, T. F. J., Lucas, D. O., Baijjalieh, S. M., and Kowalchyk, J. A. (1986). Thryotropin-releasing hormone activates a $\mathrm{Ca}^{2+}$-dependent polyphosphoinositide phosphodiesterase in permeable GH3 cells. J. Biol. Chem. 261:2918-2927.

Oberdorf, J., Vilar-Rojas, C., and Epel, D. (1989). The localization of PI and PIP kinase activities in the sea urchin egg and their modulation following fertilization. Dev. Biol. 131:236-242.

Plevin, R., and Boarder, M. R. (1988). Stimulation of formation of inositol phosphates in primary cultures of bovine adrenal chromaffin cells by angiotensin II, histamine, bradykinin, and carbachol. $J$. Neurochem. 51:634-641.

Portzehl, H., Caldwell, P. C., and Reugg, J. C. (1964). The dependence of contraction and relaxation of muscle fibers from the crab Maia squinado on the internal concentrations of free calcium ions. Biochim. Biophys. Acta 79:581-591.

Rebecchi, M. J., and Gershengorn, M. C. (1983). Thyroliberin stimulates rapid hydrolysis of phosphatidylinositol 4,5-bisphosphate by a phosphodiesterase in rat mammotropic pituitary cells. Evidence for an early $\mathrm{Ca}^{2+}$-independent action. Biochem. J. 216:287-294.

Sasakawa, N., Nakaki, T., Yamamoto, S., and Kato, R. (1989). Calcium uptake-dependent and -independent mechanisms of inositol trisphosphate formation in adrenal chromaffin cells: Comparative studies with high $\mathrm{K}^{+}$, carbamylcholine and angiotensin II. Cell. Signal. 1:75-84.

Schacht, J. (1976). Inhibition by neomycin of polyphosphoinositide turnover in subcellular fractions of guinea-pig cerebral cortex in vitro. $J$. Neurochem. 27:1119-1124.

Schacht, J. (1978). Purification of polyphosphoinositides by chromatography on immobilized neomycin. J. Lipid Res. 19:1063-1067.

TerBush, D. R., and Holz, R. W. (1990). Activation of protein kinase C is not required for exocytosis from bovine adrenal chromaffin cells: The effects of PKC(19-31), Ca/CaM kinase II(291-317) and staurosporin. J. Biol. Chem. 265:21179-21184.

Van Rooijen, L. A., Rossowska, M., and Bazan, N. G. (1985). Inhibition of phosphatidylinositol-4phosphate kinase by its product phosphatidylinositol-4,5-biphosphate. Biochem. Biophys. Res. Commun. 126:150-155.

Waymire, J. C., Bennett, W. F., Boehme, R., Hanteins, L., Gilmer-Waymire, K., and Haycock, J. (1983). Bovine adrenal chromaffin cells: High-yield purification and viability in suspension culture. J. Neurosci. Methods 7:329-351.

Whipps, D. E., Armston, A. E., Pryor, H. J., and Halestrap, A. P. (1987). Effects of glucagon and $\mathrm{Ca}^{2+}$ on the metabolism of phosphatidylinositol 4-phosphate and phosphatidylinositol 4,5bisphosphate in isolated rat hepatocytes and plasma membranes. Biochem. J. 241:835-845.

Whitaker, M. (1985). Polyphosphoinositide hydrolysis is associated with exocytosis in adrenal medullary cells. FEBS Lett. 189:137-140.

Wilson, S. P., and Kirshner, N. (1983). Calcium-evoked secretion from digitonin-permeabilized adrenal medullary chromaffin cells. J. Biol. Chem. 258:4994-5000. 